\title{
The Two Opposing Impacts of Heritage Making on Local Communities: Residents' Perceptions: A Portuguese Case
}

Luís Silva

Centre for Research in Anthropology (CRIA/FCSH - UNL), Lisbon, Portugal. luis.silva98@gmail.com

in: International Journal of Heritage Studies, 2014, Vol. 20, N. . 6, 616-633, DOI: 10.1080/13527258.2013.828650, http://www.tandfonline.com -- please cite published version --

\begin{abstract}
This article examines the impact associated with the making of heritage and tourism at a destination. Special attention is paid to the residents' perceptions of the impact. The examination is focused on the rural village of Sortelha, in Portugal, where, in recent decades, a state-led programme was implemented in order to renovate the historic buildings and built fabric and to generate benefits for the local community. Based on ethnographic materials collected in 2003, 2009 and 2013, the study demonstrates that the making of heritage may give rise to two opposing impacts simultaneously - increased social cohesion and place pride, on the one hand, and envy and competition (and, hence, social atomization), on the other hand - and that residents are entirely cognizant of the tension between the two. The study has the potential to contribute to both the theoretical and the applied literature on heritage making.
\end{abstract}

Keywords Built heritage sites, conservation, tourism, impact, residents' perceptions

\section{Introduction}

The physical, economic and socio-cultural impact of tourism on local communities is fertile ground for research in tourism studies (e.g. Moon 1989, Murphy 1985, Picard 1995). Though most of the studies are more concerned with general tourist destinations than with heritage sites, the twenty-first century has seen a number of publications on the impact of heritage tourism upon local communities (e.g. Di Giovine 2009, Hampton 2005, Silverman 2002). Many of the studies focus specifically on World Heritage Sites. There is paucity of research on heritage sites designated at different levels (national, regional or local). In addition, most studies investigate the actual or potential impact of tourism on local communities rather than the residents' perceptions of the impact. Yet, the latter is a relevant topic of research in the field of tourism (e.g. Ap 1992, Nash 1996).

In recent decades, the conservation and commoditisation of cultural heritage have also been increasingly propagated and mobilised as strategies to promote socioeconomic development in many places in the world (e.g. Graham, Ashworth and Tunbridge 2000, Hassan, de Trafford and Youssef 2008, World Bank 2001), including European and Portuguese rural communities (e.g. Council of Europe 2008, Silva 2011, Silva and Figueiredo 2013). Underpinning this widespread support for heritage making is the assumption that it provides a number of benefits to local communities (i.e. human settlements in close proximity to a given heritage site (Joppe 1996)), such as increased income through the creation of new jobs and businesses in tourism-related activities, a sense of identity, or a uniqueness of place, and pride. Particular attention is given to built heritage, including military, religious and vernacular architecture.

Interest in historic buildings and rural architecture emerged in the late nineteenth century, in the context of industrialization and the emergence of national identity building processes (Lowenthal 1998, Samuel 1994). In Portugal, as in other European 
countries, historic monuments and forms of rural architecture were turned into traits of national identity, particularly during Salazar's dictatorship (1926-1974) (e.g. Leal 2000). There has been a renewed interest in historic and rural architecture during the last three decades, but within a different context. The main objective is no longer to foster national identity, although this is not entirely absent, but to generate tourism revenue for local communities (Silva 2011, 2012).

This is evident in the state-led programmes that promote the renovation of historic buildings and the built fabric for tourism in the Portuguese countryside, of which the Recovery Programme for the Historic Villages of Portugal (hereafter HVP) is a striking example. Here one witnesses a shift from heritage constructed for the purposes of national identity building to heritage constructed for touristic consumption and economic profit (Alsayyad 2001, Rowan and Baram 2004a). It is this cultural practice of heritage making (e.g. Silva and Santos 2012, Smith 2006) and its outcomes that are under analysis in this article, which focuses on one of the most popular Historic Villages of Portugal.

The entwining of heritage and tourism has been examined by numerous authors (e.g. Kirshenblatt-Gimblett 1998, Robinson et al. 2000, Timothy 2011). Some scholars (Garrod and Fyall 2000, Landorf 2009, McKercher and du Cros 2002) focus on the supply of heritage and its management, while other authors and institutions (ICOMOS 1993, Orbasli 2000, Poria, Butler and Airey 2003, Richards 1996, Shackley 1998a) deal with the demand for heritage tourism and/or visitor management. The uses of heritage were scrutinized by Graham, Ashworth and Tunbridge (2000), as well as by Smith (2006). The marketing of heritage was studied by Bennett (1995) and Rowan and Baram (2004b), while the notion of 'community' within the field of heritage was studied by Dicks (1999) and Waterton and Smith (2010). Less attention has been paid to the impact of heritage making on local communities, and notably in Portugal.

In addition, research into this topic has shown conflicting results; the making of heritage can generate benefits for local communities, such as entrepreneurial activity, economic growth, a sense of locality and pride (e.g. Evans 2002, Shipley and Snyder 2012, Timothy 2011), whilst it can also provide a limited contribution to the economic well-being of the community involved and give rise to many other social impact, some of which carry negative implications (e.g. Herzfeld 1991, 2010, Schellhorn 2010, Winter 2008); in many cases it engenders both positive and negative effects (e.g. Graham, Ashworth and Tunbridge 2000, Hampton 2005, Jimura 2011).

From a more critical perspective, Poria and Ashworth (2009) also consider the division of people into groups associated with 'heritagization' as a 'current resource for conflict'. The authors (2009, p. 522) distinguish 'heritagization' from conservation and preservation of heritage. The former is a social process in which heritage is used, via heritage tourism, to achieve certain socio-political objectives, mainly establishing solidarity among members of a group (national, ethnic, religious, etc.), by highlighting their uniqueness and, thereby, legitimizing a certain socio-political order and ideological framework. Conservation and preservation, in turn, are linked to objects and the supply of cultural tourism. In their discussion of the anthropological literature on tourism, Leite and Graburn (2009, p. 45) further note that heritage can play an integrative or divisive role - fomenting social cohesion among members of a group at large or 'fomenting competition between ethno-national groups in plural societies and between status groups and classes in stratified societies', as well as, especially in the case of World Heritage, between nations.

This article tackles the impact associated with heritage making and tourism at the rural Portuguese village of Sortelha from the standpoint of its residents to 
demonstrate that the making of heritage may have two opposing impacts at the same time - with implications on social cohesion - and that residents are fully aware of the tension between the two. By doing so, the article shows the relevance of ethnography for the study of heritage impact (Bendix 2009) as well as the relevance of 'interventions' by anthropologists on (heritage) tourism (Abram 2010). This contribution will be developed as follows. After a description of the study methods and a characterization of the village, respectively, this article puts forward an analysis of the collected materials.

\section{Study methods}

In tourism studies generally, research into the impact of tourism on local communities from the perspective of residents has followed two main lines of approach - one which is synchronic, the other diachronic. The former is the most common approach (e.g. Aguiló and Roselló 2005, Besculides, Lee and McCormick 2002, Jimura 2011). The weakness of this approach is that it fails to capture the dynamic character of tourism (Ap 1990, p. 611; see also Butler 2009). In this regard, research has shown that the perceptions of residents about tourism and its impact may vary over time, shifting from a condition of enthusiasm in an initial stage of tourism development to one of disappointment in a later stage (Johnson, Snepenger and Akis 1994, Py-Sunier 1978, Sharpley 1999, pp. 262-267).

In what is one of the two hallmarks of anthropology's distinctive approach to tourism as an object of study - the other is holistic analysis - (Leite and Graburn 2009, p. 36), this study is grounded on ethnographic field research carried out in 2003 (five months), 2009 (two months) and 2013 (one week) in the village of Sortelha, as part of two research projects. This author worked and stayed in Sortelha, expanding the networks of acquaintances and respondents gradually. The main methods of data collection were participant observation, a set of 60 semi-structured interviews with residents and detailed field notes.

Of the 60 interviews, most of which were conducted in 2003 (40) and 2009 (15), and which lasted 20 minutes on average, 15 were recorded and notes were taken on the remainder. I had numerous other informal discussions with villagers and participated in family and village events. The purpose was to investigate the perceived impact of the HVP programme and tourism at the destination. Of the 13 perceived impacts, nine were introduced for discussion by the researcher and the others (litter, the community's economic sustainability, privacy and social relations) emerged from the fieldwork. This was complemented by six semi-structured interviews with the coordinator of, and the architects associated with, the HVP programme conducted in 2008-2009.

\section{Context and background}

Sortelha is part of the municipality of Sabugal, some 30 kilometres from the city of Guarda in eastern Portugal. Sortelha is an example of the socioeconomic transformation that rural areas of Portugal have been undergoing for the past five decades. First, as population censuses show, the number of this parish's inhabitants has decreased $70 \%$ between 1960 and 2011, when the lowest number of inhabitants in the last 150 years was recorded (444). About half of the parish population live in the village of Sortelha, which is the context under examination in this article and which includes two separate places: the walled village and the outskirts, locally referred to as Vila and Arrabalde, respectively. The resident population of Sortelha is elderly (51\% of residents are over 65 years old), relatively poor, and has low levels of formal education and training (the illiteracy rate is over $20 \%$ ). 
Second, inhabitants relied on a precarious subsistence economy based on agriculture until the 1950s. In the last four decades, but especially since the 1990s, along with the decline of agriculture, Sortelha has seen the rise of economic activities linked to the secondary and, mainly, tertiary sectors, in which public/municipal administration and tourism occupy important positions. This change has been strongly encouraged by the Portuguese government, which seeks to find in rural tourism a lever for socioeconomic development (e.g. Cavaco 1995, Silva 2009), but it has also relied on private initiatives.

The first tourism business, in the form of a 'traditional' restaurant, was set up in Sortelha in the early 1970s, through the initiative of an aristocratic couple from greater Lisbon who owned vast estates and a manor house in the village, in partnership with a small group of lawyers, doctors and engineers, also from greater Lisbon, with whom, in the previous decade, they had discovered and appropriated the place as something of a romantic adventure. This initiative was followed by subsequent ones, both private and public, aimed at creating a business out of tourism.

In terms of private agents, Luisa Charters (Seville, 1929- ...), viscount ${ }^{1}$ of São Sebastião through marriage, played a critical role. In the 1970s, she settled in the village and began to promote tourism to renovate its social and economic fabric. Until recent years, when she returned to greater Lisbon because of her age, she created an ethnographic association and a folkloric group; ran a tourism business that included three small accommodation units and an antique and crafts shop; promoted the revitalization of bracejo handicrafts (i.e. handicrafts made from giant feather grass) (see 'Place identity...' below); set up a workshop for the manufacture and restoration of carpets (which is all but closed today); and published a book on local history, traditions and customs (Charters 1999).

Although Sortelha was considered by the Portuguese government as one of the priority areas for the development of rural tourism in 1983 (Administrative order no. 102/82, from January 19, 1983), the most important of public actions aimed at promoting tourism here was the HVP programme.

\section{A programme for the 'monumental' rural villages of Portugal}

Designed by the national government and the Commission for the Development and Coordination of the Central Region, which coordinated it, and funded by the European Union, the HVP programme was implemented between 1995 and 2006 in 12 rural villages located in the eastern side of the Central region of Portugal, in cooperation with the Portuguese historic conservation agencies (the former IPPAR and the former DGEMN $),{ }^{2}$ the foundation INATEL, the municipalities and private entities. The objectives were to renovate the historic buildings and the built fabric (i.e. built heritage) and to generate tourism revenue for the village populations (MPAT and MCT 1994, PPDR 1995).

The village of Sortelha entered the programme because it met various selection criteria, namely, 'existence of designated architectural heritage', 3 'formal unity of the urban fabric', 'historical and cultural interest', and a 'desertification rate' (MPAT and MCT 1994, p. 2). Much like the residents of the other Historic Villages of Portugal (Silva 2012, p. 490), and reflecting the top-down nature of the programme, the village population of Sortelha did not participate in the decision-making process, but only in a sub-programme related to the private buildings located in the historic area. Presented by the municipal government to the coordinating body, the application was based on the village plan designed by architects, both those working for the municipality of Sabugal and those working for the historic conservation agencies. The village plan identified 
what work was to be done in the village of Sortelha and the entities that would be responsible for it (PPDR 1995, pp. 26-28).

According to Kirshenblatt-Gimblett (1998, pp. 149-151), heritage practices endow objects, buildings, technologies, or ways of life with a 'second life as heritage', a life as 'representations of themselves' within a tourism economy, and 'heritage is created through a process of exhibition (as knowledge, as performance, as museum display)'. In a similar vein, Dicks (2003, pp. 34-37) argues that places are handled, modelled and even simulated to promote 'the cultural economy of visitability'. Sortelha is a good example of this trend, as the ultimate goal of the HVP programme was to put built heritage on display for consumption through tourism, in a process that Urry (1999, p. 220) would describe as 'designing for the gaze'. For Urry (1999, p. 220), 'architects and architectural practices are of major importance in shaping the contemporary tourist gaze'.

This is evident in the HVP programme, in which architectural knowledge was mobilized by public authorities as a technology of government to define architecture as an object of touristic consumption and to determine the conduct of individuals (Silva 2011, p. 49). In Sortelha, not only the setting of the scene was designed by architects, as noted above, but also much of the more than two million Euros that the programme invested here was spent in rendering the citadel 'historical'. This included interventions on historic monuments and other buildings, both public and private; renovation of public spaces, basic infrastructure, pavement of streets, new street lighting, and general embellishment (Boura 2002, p. 17).

Considering the data collected through fieldwork, and interviews with the architects, interventions on historic monuments followed different preservation- or conservation-oriented methodologies in line with current architectural knowledge and international conventions and recommendations on the subject. Some monuments were preserved, or, in other words, subject to intervention in order to maintain the stability of their structures, which may well have been ruined. This occurred in the ruins of the church of Santa Rita. Other monuments, in turn, were conserved, as 'conservation may involve preservation but also restoration of the physical fabric' (Graham, Ashworth and Tunbridge 2000, p. 16). This could be observed in the fortress walls and in the church of Nossa Senhora das Neves, which is the main church. As the director of the former IPPAR stated in an interview at his office in the city of Castelo Branco in 2009:

'Interventions on monuments entailed restoration, rehabilitation or renovation, depending on the case. [...] All interventions were registered and dated, because we mainly followed the criterion of historic authenticity, but always made it compatible with the criterion of aesthetic authenticity, when it was necessary. [...] Historic authenticity embraces the different periods of the monument'.

Thus, interventions on monuments reflect the modern understanding of heritage as an accumulation of historical periods, of which the present is the latest. In contrast, interventions on other buildings reflect the purist ideal of maintaining the past in its original state. In fact, the aims were not only to restore the facades and roofs of buildings but also to eliminate the modern and spurious industrial materials, such as concrete and aluminium, which are considered to contaminate the prestigious materials of the past, such as stone and wood. The stonework of the facades was uncovered, while the roof tiles were standardized (both in terms of type and of colour) and the use of wood became compulsory for outward-facing doors and windows. Television antennas and aerial electrical power lines were also replaced by underground communication and 
electrical cables. The purpose was to hide modernity in a context that is being rendered historical, or, in other words, to increase authenticity, in the sense of 'mimetic credibility', which means the production of a 'historic site believable to the public' (Bruner 1994, p. 399). In addition, 'markers' were put at the entrance to and inside the citadel, placing it 'out of real time and space' (MacCannell [1976] 1999, p. 41) and guiding tourists to what is distinctive and worth viewing.

\section{The viewpoint of residents}

Fieldwork carried out in Sortelha shows that the village population is divided over the benefits and costs brought by built heritage making and tourism. This is referred to in the 13 impacts described and analysed in this section. Although this is not a enclosed and homogeneous community, as in some places (e.g. Sharma and Dyer 2009) and not in others (e.g. Aguiló and Roselló 2005), in Sortelha, the perceptions of residents regarding heritage and tourism impacts do not vary significantly according to social and demographic characteristics (e.g. age, education, gender and place of residence), or to economic reliance on tourism. In addition, overall, they have not changed significantly in the last 10 years.

\section{Site conservation and image, housing and property values}

Regarding site conservation and image, residents often state that with the implementation of the HVP programme in Sortelha, the old village has become new. This, for example, is the case of a tourism entrepreneur interviewed in 2009, to whom 'the heritage of Sortelha, which is a medieval village, was restored, and this improved significantly the image of the village'. Likewise, a civil servant interviewed in 2013 is of the opinion that the designation of Sortelha as Historic Village of Portugal and its conservation had 'the virtue of restoring many houses and roofs within the Vila which were in ruins, and of enhancing the beauty and attractiveness of the village'.

However, there is a strong criticism of the interventions on religious and domestic architecture. With reference to the church of Santa Rita, residents claim that this should have been 'restored' instead of 'preserved in ruins and without a roof'. The situation of the main church is described by an informant in her 50s:

'The work in the church was poorly done. The high altar became damaged because of rainwater when the church had no roof. They also took away the choir and the stones that supported it, and the church has become very small. The roof was never well restored, as the tiles break easily leading to water leaks. Moreover, the work took a long time to be completed.' (Field journal, September 2009)

In addition, residents consider that the conservation initiative did not improve their housing conditions, for three reasons. For a start, the great majority of residents do not live in but around the heritage site. Though the outskirts of the village were considered as in dire need of a 'disciplinary urban plan' by the programme (MPAT and MCT 1994, p. 6), it intervened only in the buildings located in the citadel. In the process, most of the approximately 100 buildings located there - of which the majority are privately owned and representative of lower-class architecture - underwent work on their facades and roofs at the expense of the programme. Included here are 15 old barns and 70 houses (which account for $26 \%$ of the houses available in Sortelha), of which 18 are in a non-habitable state.

Although some buildings were converted into tourism-related businesses, most of them are vacant, including 12 barns owned by a tourism society founded in the $1960 \mathrm{~s}$ 
and dismantled in 1974, and some other buildings owned by various city dwellers from outside that were not restored. There are also 12 vacation houses owned mainly by other Portuguese urbanites who use them infrequently. In fact, today, only three of the 234 permanent residents live in the citadel; the others live in the outskirts of the village, where the retirement home (which currently hosts 18 residents) and some tourismrelated businesses are also based.

In contrast to many other places where heritage site designation has engendered gentrification (e.g. Collins 2008, Herzfeld 2010), in some cases even 'spatial cleansing' (Herzfeld 2006), and a split between the site and its surroundings (Jimura 2011), in Sortelha, heritage making did not foster this process. Inhabitants settled in the outskirts of the village from the 1960s onwards, for multiple reasons. As an interviewee stated in 2003:

'In the early 1960s, all houses in the Vila were inhabited; more than 100 people lived here. Then, many locals emigrated to France and Germany, and some wealthy people from outside started buying the houses of these emigrants. A tourism society bought 12 buildings and its members bought some others as well. They offered higher prices to their owners to buy the houses and they accepted, because the money would allow them to reunite the family in the country of immigration or to build new and larger houses in the Arrabalde.'

Besides, unlike the Japanese case studied by Jimura (2011), people living around the built heritage site of Sortelha do not envy those living in it and would not like to live there, though some have claimed the right to receive the funds for renovation granted to the owners of the properties located in the site. This is because of the small size of the houses, the perceived and actual lack of free space within the citadel and its limited residential population. In the words of an interviewee in his late 30s in 2013:

'I was born and lived within the Vila until the age of 21. But I prefer to live in the Arrabalde, because I'm more at ease, there are more people and, when I go out in the street, I always see someone to whom I can talk. Hardly anyone lives in the Vila; if I lived there, I would have no one to talk to. [Laughs...] Here I also have a yard, I can park the car in the yard, or in the garage, and I have a small garden. None of this can happen in the Vila, because the spaces are very small, as are the houses.'

In fact, the historic area of Sortelha is swiftly becoming an 'empty meeting ground' (MacCannell 1992). This is the main reason for the tension between historic conservation and the secular use of buildings observed in many places worldwide (e.g. Fabre 2010, Gravari-Barbas 2005, Herzfeld 1991, 2006, 2010), or, in other words, the potentially problematic co-existence of first and 'second life' (Kirshenblatt-Gimblett 1998) in the same houses (Silva 2011) is less frequent here.

Another reason why residents consider that the programme did not improve their housing conditions is that the work was poorly done in most cases, as the new roof tiles fall and break easily leading to leaks, while the new wooden outward-facing doors and windows do not provide proper insulation:

'The work on roofs was poorly done, for the roof tiles break easily causing leaks. On the doors and windows, they replaced the typical chestnut wood or oak wood by pine that was not yet ready to be used. Quickly, the doors and windows became warped 
and stopped providing proper insulation.' (Resident of the citadel, Field journal, May 2003)

Furthermore, the programme did not fund indoor improvements or the connecting of properties with a view to expanding their available interior space, and it carried out indoor building work only for demolition or to create tourism-related businesses.

Yet, as has been observed in other built heritage sites (e.g. Herzfeld 1991, Shipley and Snider 2012), in contrast to numerous others (e.g. Graham, Ashworth and Tunbridge 2000, p. 134), the idea that the heritage programme and tourism have led to an increase on the value or price of properties, most especially of those located in the citadel, is a recurring refrain in the residents' discourses. Nevertheless, for some residents, this is not a positive, but a negative impact:

'Tourism has also increased the sale price and the rental price of houses and commercial establishments. My husband and I have had a café rented in the Vila, but the value of the rent was very high and we were forced to leave the business.' (Artisan, Field journal, October 2009).

A problem that residents often associate with the designation of the heritage site of Sortelha lies in the subsequent restrictions on new housing construction in the outskirts of the village, which are considered responsible for the out-migration of the few newly married couples. As a resident stated in an interview in 2013, 'the negative consequence is that they have created a "green area" in the Arrabalde, where the building of new houses is prohibited. There are young couples who went to live in Sabugal because of this'.

\section{Tourism growth, litter and the community's economic sustainability}

In Sortelha, as in many other places (e.g. Di Giovine 2009, Winter 2008), though this is not always the case (e.g. Landorf 2009), residents consider that the designation and display of the built heritage site have led to tourism growth, both in terms of demand and of supply. Regarding demand, it is maintained that Sortelha has shifted from an elite destination for a small group of upper-class city dwellers in Portugal to a popular destination, one that attracts an increasing number of people pertaining to the lower classes, from both urban and rural areas. Between $2007^{5}$ and 2012, Sortelha registered more than 338,000 visitors. As is often the case for heritage sites (e.g. Evans 2002, Jimura 2011), the great majority of visitors were domestic (80\%), while the Spanish due to geographic proximity - and the French accounted for much of the remaining share.

On the supply side, residents perceive a rapid increase in the number and variety of tourism-related businesses and, thus, the diversification of sources of income:

'Tourism is a major source of revenue for Sortelha. There are a number of tourist accommodation units and craft-shops, three restaurants... some residents sell dried figs, others sell liquors or bracejo handicrafts... Everyone has invented something to sell and everyone earns money.' (Tourism entrepreneur, interviewed in 2003)

'If it were not for tourism, Sortelha would be a dead village like many other villages in rural Portugal. There are two restaurants, a number of tourist accommodation units and three cafés in Sortelha. These businesses exist because of tourism and tourists, 
not because of residents, and they provide money to the owners and to some workers'. (Civil servant, interviewed in 2013)

Currently, the local tourism industry comprises five small tourist accommodation units providing a total of 15 beds, three cafés/snack-bars, two restaurants, one local shop and a tourist office. Few of these businesses were created before the HVP programme, which funded the creation of three tourist accommodation establishments. The tourist office is state-owned. Other businesses are owned by private entrepreneurs, both locals and newcomers of predominantly urban origin. They have the small-scale and family-based nature of most businesses operating in rural tourism (e.g. Cavaco 1995, Lane 2009). Tourism in the village employs nine workers - seven of whom are residents -, two thirds of whom are full-time. But the percentage of residents directly and indirectly associated with tourism is $15 \%$. Women account for an important share here, both as entrepreneurs and, mainly, as workers, as is usual in rural tourism (e.g. Bouquet and Winter 1987, Lane 2009; on the impact of tourism development on gender, see Leite and Graburn 2009, pp. 41-42). Included here are also five women who produce and sell bracejo handicrafts and/or homemade food products to tourists, either outdoors in the street, or indoors in a building near the castle.

Nevertheless, some residents whose livelihood does not rely on tourism state that economic benefits accrue to only part of the village population: 'Tourism is good for cafés, restaurants and tourist accommodations; to me, it provides no money' (Retiree; Field Journal, April 2013); 'Tourism is good for people who have money to invest, for people who have houses for rent, restaurants... Tourism provides money for these people, not for others' (Civil servant, interviewed in 2013).

In addition, along with an increase of litter in the village, which is a frequent impact of tourism (e.g. Mathieson and Wall 1982, Timothy 2011), residents fairly often complain of the seasonality of tourism, a feature that also seems to be characteristic of tourism (e.g. Butler 2001), notwithstanding the existence of exceptions (Jimura 2011). In their view, tourism is a highly seasonal activity that does not provides enough money to make a living, for which it is necessary to have complementary sources of income. As a resident stated in 2013:

'The snack-bar is no longer operating outside the summer months because it's not worth it; it's a waste of time and of money, as I don't even earn enough money to pay for electricity. Now, during the week, I work in construction and, on weekends, I produce wooden handicrafts to sell in the summer.' (Field journal, April 2013)

Moreover, and this is the only point in which the perceptions of residents have changed between 2003 and 2013, the widespread enthusiasm shown in 2003 has declined in more recent years, as residents realized that, though relevant, the expected contribution of tourism to the economic sustainability of the local community has proved to be exaggerated, as occurs in many other destinations worldwide, where 'the positive economic effects of tourism frequently fall significantly short of expectations or predictions' (Cohen 1984, p. 384). In their view, this is a result of expectations created by public authorities, a situation observed in many other contexts in rural Portugal (Ribeiro and Marques 2002).

In fact, the increasing number of visitors recorded in recent years has been accompanied by a not insignificant decline in the number of tourism businesses and of locals engaged in them - from $21 \%$ of the village population in 2003 (Silva 2009, p. $157)$ to $15 \%$ in 2013 . This is because some businesses have closed, either because of 
aging or death of the entrepreneur, or because they have proved to be economically unviable and were not replaced. Jimura (2011) found a similar case in Japan, where the number of tourist accommodation units has decreased after World Heritage Site designation, while the number of tourists has increased rapidly.

\section{Place identity, pride, awareness of heritage and handicrafts}

In what Poria and Ashworth (2009) consider a 'current resource for conflict', it is widely accepted in the research literature that heritage is used to create and legitimize collective identities, embracing a wide range of human attributes (language, religion, ethnicity, nationalism, etc.) (e.g. Goulding and Domic 2009, Handler 1988, the special issue of the International Journal of Heritage Studies 2006 (12: 1)). Representations of place through built heritage play a central role in these processes of inclusion and exclusion of people (e.g. Ashworth, Graham and Tunbridge 2007, Dicks 2003), even though 'the practice of architectural and urban conservation may well tend towards a standardization of forms, a homogenization of places and thus a reduction in local diversity' (Graham, Ashworth and Tunbridge 2000, p. 217), as the above-mentioned intervention on the built fabric of Sortelha illustrates.

Similarly, the representation of the built heritage site of Sortelha as historic plays a central role in the ways in which place is rendered specific and differentiated:

'Our village is unique. Sortelha is a well-preserved, walled village, with a medieval castle inside, which played a central role in the history of our country, most especially during the wars against the Spanish'. (Retiree, Field Journal, September 2009)

'Although there are 12 Historic Villages of Portugal, Sortelha is unique. For some reason, it is the second most visited of the Historic Villages. [...] Sortelha is a wellpreserved and authentic medieval village, made of stone, without dissonant modernisms and surrounded by fortress walls, and this is what differentiates us from others'. (Tourism worker, interviewed in 2013)

This awareness of the uniqueness of Sortelha has grown in the years following the designation and display of the built heritage site, leading to increased social cohesion amongst residents.

Moreover, for residents of Sortelha generally, as for those of many designated World Heritage Sites (e.g. Evans 2002, Shackley 1998b, Jimura 2011), the built heritage site now functions as a source of personal and collective pride. In the words of a resident in her 60s interviewed in 2009 , 'We began to like more of our village, because the village has become more beautiful and more valuable. Tourists always say that this village is very beautiful, and this is always good for us' (Field journal, October 2009). Likewise, another resident in her 40s stated in 2013 that 'we are proud of our village being nationally and internationally known as a Historic Village of Portugal' (Field journal, April 2013).

In addition, and consequently, residents perceive a raised awareness of built heritage. This is clearly expressed by two interviewees:

'The programme and tourism had made us aware of our rich historic heritage. We thought we just had stones, but these stones are very valuable, as they are very ancient and tell part of the history of Portugal'. (Retiree, Field journal, July 2003) 
'Tourism teaches us to value what we have best. Sometimes, tourists notice, and call attention to, details in our historic village that previously were unnoticed by us'. (Artisan, Field journal, April 2013)

A good example of this sense of locality and increased pride and awareness of heritage is the claim by many residents, according to whom part of the heritage of Sortelha was expropriated by public authorities, because some of the relics found there during the intervention were 'stolen', a statement that derives from the idea that they have property rights over these items and consider them accepted ingredients of place identity:

'The people of Sortelha were stripped of part of their heritage, since there are items of value that have been found here and were taken, some to the Museum of Sabugal, others to nobody knows where. There were some medieval stones and even the skeleton of a person that was found in an anthropomorphic grave near the church that were taken to the Museum of Sabugal. As they are part of Sortelha's heritage, those items should have been kept here to be shown to tourists in a future museum of Sortelha.' (Tourism entrepreneur, interviewed in 2009)

As part of this process of self-consciousness of local culture/heritage, the revitalization of handicrafts, most especially of bracejo handicrafts, is commonly perceived as a positive impact of tourism as well as an aspect of place identity, conveying 'the fascinating difference, even exoticism, of the host community' (Leite and Graburn 2009, p. 44). Residents of Sortelha recall that, in the past, they used bracejo to make beds for cattle, as well as pallets, brooms and, occasionally, hats for people. This practice fell into disuse in the second half of the twentieth century, but it was recovered for tourism in the early 1980s, by instigation of Luisa Charters. In the process, industrial materials such as raffia have replaced traditional materials such as peeled bramble bark at the intersections of the bracejo ribs, and bracejo began to be used to produce new, mainly decorative objects, of which the miniature baskets are a good example. This is an example of what Mckean (1978) called 'cultural involution', in that handicraft survives extinction because tourism makes it economically viable.

\section{Privacy and host-host relationships}

Research has shown that tourism development often entails loss of privacy for host communities (e.g. Boissevain 1996, Jimura 2011). Sortelha is a good example of this trend, as the following statements from two residents illustrate:

'Thirty or 40 years ago, in all of the inhabited houses in the Vila, the doors were kept open until people went to sleep. Today, this does not happen because of the tourists who enter into people's homes if the doors are open, and also because of what one hears about robberies on TV and radio. (Retiree, resident of the citadel, Field journal, October 2009)

'With the presence of an increasing number of tourists in Sortelha, it is natural that older people feel their privacy invaded. Sometimes, tourists are also unkind, since they ask the women who sell bracejo in the village to take off their hats and to pose for photos, and this is upsetting for them. Some women only allow themselves to be photographed if tourists buy a basket or give some money in exchange.' (Artisan, interviewed in 2013) 
Although tourism impact studies often ignore host-host relationships, research has shown strong evidence that tourism development may exert a significant negative impact on social relations within the community involved (e.g. Cohen 1984, Harrison 2001, Silva 2013). Sortelha is in no way immune to this impact, since, as residents point out, tourism has created a new arena for social competition and tension amongst stakeholders, with implications on interpersonal relations:

'There is much envy among the women who sell bracejo to tourists in the Vila. They argue over selling places and are envious of each other sales. There are women of the same family who do not talk to each other because of this. This also occurs among restaurant owners, who accuse each other of cutting their prices to steal customers.' (Artisan, Field journal, July 2003)

'The problem of this village is that there is much envy. Before I opened the bar, whenever I came to visit Sortelha, I was welcomed by everyone. When I opened the bar, some people's attitude towards me changed. I had to face many problems to be able to open the business here, and I was threatened through letters and words. A café owner even asked to some boys to throw stones at the terrace of my bar in order to drive away customers (Tourism entrepreneur, Field journal, September 2009)

The competitive nature of the industry is partly a result of a scarcity of economic resources but also reflects the characteristics of social relations within the community. Anthropologists (e.g. Bailey 1971, Campbell 1964, Cole 1991, Pina-Cabral 1986) have shown that envy and competition for resources and social prestige are characteristics of social relations in societies with face-to-face interaction, including European coastal communities and peasantries. In a small, close knit community like that of Sortelha, envy and competition are, thus, almost inevitable. Ultimately, this offsets the abovementioned increased social cohesion associated with the 'heritagization' process that led to the creation of a sense of uniqueness in Sortelha.

\section{Conclusion}

This article set out to examine the impact associated with heritage making and tourism on local communities from the standpoint of residents, through a longitudinal ethnographic case study focused on a single Historic Village of Portugal.

The research has shown that, in the last decade, residents of Sortelha have been divided over the benefits and costs of heritage making (here represented by the HVP programme) and tourism. Built heritage site conservation and image, as well as place identity, pride and awareness of heritage, tourism growth (both in terms of demand and of supply) and the revitalization of handicrafts, rank highly amongst the village population. However, negative impacts offset these benefits, including litter, loss of privacy, restrictions on new housing construction in and around the site which are considered to hamper the social reproduction of the local community, the limited contribution of tourism to the community's economic sustainability - due to high expectations or predictions, the seasonal bias and the uneven distribution of tourism revenues, which accrue to only $15 \%$ of residents -, envy and competition. Residents also perceive an increase of property values or prices, which most of them regard as positive.

Regarding heritage studies, the fact that the making of heritage has generated perceived benefits and costs at the destination is consistent with the findings of other 
researchers working in this area (e.g. Evans 2002, Jimura 2011). In addition, the study adds nuance to the entwining of heritage and conflict. Not only is the enunciation of heritage inhabited by dissonance and contestation (Graham, Ashworth and Tunbridge 2000, Tunbridge and Ashworth 1996) and 'heritagization' a 'resource for conflict' (Poria and Ashworth 2009) but also its commodification through tourism has the potential to adversely affect social relations amongst host communities (compare Jimura 2011, Schellhorn 2010).

Moreover, the making of heritage can play an integrative or divisive role (Leite and Graburn 2009) but also these two roles at the same time; in the same manner that tourism can promote cultural reinforcement and change (Moon 1989). In fact, it is argued in this article, the making of heritage may give rise to two opposing impacts simultaneously - increased social cohesion and place pride, on the one hand, and envy and competition (and, thus, social atomization), on the other hand - and residents are totally cognizant of the tension between the two.

The case of Sortelha can also be taken into consideration in the management of built heritage sites. Graham, Ashworth and Tunbridge (2000, pp. 134-135) use what they called 'neighbour's dilemma' to illustrate the complex nature and the frequent failure of the relationship between the costs of investment in heritage and its return. Here is evidence that this is exacerbated when it comes to vacant private buildings whose owners are not involved in its continuous maintenance and when there is no community involvement in heritage management, or reconciliation among various players with diverging aspirations (Orbasli 2000).

\section{Notes}

1 Viscount is a nobility title characteristic of the Portuguese monarchy. In the Middle Ages, viscounts received from the King a piece of land, where they had the power to govern according to their will, thereby assisting in the administration of the kingdom.

2 These agencies disappeared in 2007, as a result of the creation of the Portuguese Institute for the Management of Architectural and Archaeological Heritage.

3 The medieval castle was accorded official protection status as a 'national monument' in 1910, while the pillory was designated a 'building of public interest' in 1933. A pillory is a stone column placed in a public place in a town or village where criminals were exposed and punished. An artefact is considered to be of 'public interest' when it represents a cultural value of national importance, but for which the system of protection for 'national monuments' is considered excessive.

4 All translations by the author.

5 The tourist office was created in Sortelha in mid-2003, but the information produced by it until 2006 is unreliable, as it did not operate on a daily basis and its previous location was less visible than its current position at the entrance of the citadel.

\section{References}

Abram, S., 2010. Anthropology, tourism and intervention. In: J. Scott and T. Selwin, eds. Thinking Through Tourism. Oxford: Berg, 231-253.

Aguiló, E. and Roselló, J., 2005. Host community perceptions. A cluster analysis. Annals of Tourism Research, 32 (4), 925-941.

Alsayyad, N., 2001. Global norms and urban forms in the age of tourism: manufacturing heritage, consuming tradition. In: N. Alsayyad, ed. Consuming tradition, manufacturing heritage: global norms and urban forms in the age of tourism. New York: Routledge, 1-33. 
Ap, J., 1990. Residents' perceptions research on the social impacts of tourism. Annals of Tourism Research, 17 (4), 610-616.

Ap, J., 1992. Residents' perceptions on tourism impact. Annals of Tourism Research, 19 (4), 665-690.

Ashworth, G., Graham, B. and Tunbridge, J., 2007. Pluralising pasts: heritage, identity and place in multicultural societies. London: Pluto Press.

Bailey, F., ed., 1971. Gifts and poison: the politics of reputation. New York: Schocken Books.

Bendix, R., 2009. Heritage between economy and politics: an assessment from the perspective of cultural anthropology. In: L. Smith and N. Akagawa, eds. Intangible Heritage. Oxon: Routledge, 253-269.

Bennett, M., 1995. Heritage marketing: the role of information technology. Journal of Vacation Marketing, 3 (3), 272-280.

Besculides, A., Lee, M. and McCormick, P., 2002. Residents' perceptions of the cultural benefits of tourism. Annals of Tourism Research, 29 (2), 303-319.

Boissevain, J., 1996. Introduction. In: J. Boissevain, ed. Coping with tourists. European reaction to mass tourism. Providence, RI: Berghahn, 1-26.

Bouquet, M. and Winter, M., eds., 1987. Who from their labours rest? Conflict and practice in rural tourism. London: Gower.

Boura, I., coord., 2002. Aldeias Históricas de Portugal. Um Património com Futuro. Coimbra: Comissão de Coordenação da Região Centro.

Bruner, E., 1994. Abraham Lincoln as authentic reproduction: a critique of postmodernism. American Anthropologist, 96 (2), 397-415.

Butler, R., 2001. Seasonality in tourism: issues and implications. In: T. Baum and S. Lundtorp, eds. Seasonality in tourism (advances in tourism research). Amsterdam: Pergamon, 5-22.

Butler, R., 2009. Tourism in the future: cycles, waves or wheels?. Futures, 41 (1), 346352.

Campbell, J., 1964. Honour, family and patronage: a study of institutions and moral values in a Greek mountain community. Oxford: Oxford University Press.

Cavaco, C., 1995. Tourism in Portugal: diversity, diffusion, and regional and local development. Tijdschrift voor Economische en Sociale Geografie, 86 (1), 64-71.

Charters, L., 1999. Sortelha - Vila: História, Usos, Costumes. Sortelha: Author's edition.

Cohen, E., 1984. The sociology of tourism: approaches, issues, and findings. Annual Review of Sociology, 10, 373-392.

Cole, S., 1991. Women of the praia. Work and lives in a Portuguese coastal community. Princeton, NJ: Princeton University Press.

Collins, J., 2008. 'But what if I should need to defecate in your neighborhood, Madame?': empire, redemption, and the 'tradition of the oppressed' in a Brazilian world heritage site. Cultural Anthropology, 23 (2), 279-328.

Council of Europe, 2008. European heritage - sustainable development strategies in South-East Europe. Strasbourg: Council of Europe.

Dicks, B., 1999. The view of our town from the hill: communities on display as local heritage. International Journal of Cultural Studies, 2 (3), 349-368.

Dicks, B., 2003. Culture on display. The production of contemporary visitability. Maidenhead: Open University Press.

Di Giovine, M., 2009. The heritage-scape: UNESCO, world heritage, and tourism. Lanham, MD: Lexington. 
Evans, G., 2002. Living in a world heritage city: stakeholders in the dialectic of the universal and particular. International Journal of Heritage Studies, 8 (2), 117-135.

Fabre, D., 2010. Introduction: habiter les monuments. Terrain [online], http://terrain.revues.org/13888. Accessed May 2010.

Garrod, B. and Fyall, A., 2000. Managing heritage tourism. Annals of Tourism Research, 27 (3), 682-708.

Graham, B., Ashworth, G. and Tunbridge, J., 2000. A geography of heritage: power, culture and economy. London: Arnold.

Gravari-Barbas, M., ed., 2005. Habiter le patrimoine: enjeux, approches, vécu. Rennes: Presses Universitaires de Rennes.

Goulding, C. and Domic, D., 2009. Heritage, identity and ideological manipulation. Annals of Tourism Research 36 (1), 85-102.

Handler, R., 1988. Nationalism and the politics of culture in Quebec. Madison: University of Wisconsin Press.

Hampton, M., 2005. Heritage, local communities and development. Annals of Tourism Research, 32 (3), 735-759.

Harrison, D., 2001. Afterword. In: D. Harrison, ed. Tourism and the less developed world: issues and case studies. New York: CAB International, 251-263.

Hassan, F., de Trafford, A. and Youssef, M., eds., 2008. Cultural heritage and development in the Arab world. Alexandria: Bibliotheca Alexandrina.

Herzfeld, M., 1991. A place in history - social and monumental time in a Cretan town. New Jersey: Princeton University Press.

Herzfeld, M., 2006. Spatial cleansing: monumental vacuity and the idea of the West. Journal of Material Culture, 11 (1-2), 127-149.

Herzfeld, M., 2010. Engagement, gentrification, and the neoliberal hijacking of history. Current Anthropology, 51 (Supplement 2), 259-267.

ICOMOS, 1993. Tourism at world heritage sites: the site manager's handbook. Madrid: WTO.

Jimura, T., 2011. The impact of world heritage site designation on local communities: a case study of Ogimachi, Shirakawa-mura, Japan. Tourism Management, 32 (2), 288-296.

Johnson, J., Snepenger, D. and Akis, S., 1994. Residents' perceptions of tourism development. Annals of Tourism Research, 21 (3), 629-642.

Joppe, M., 1996. Sustainable community tourism development revisited. Tourism Management, 17 (7), 475-479.

Kirshenblatt-Gimblett, B., 1998. Destination culture: tourism, museums, and heritage. London: University of California Press.

Landorf, C., 2009. Managing for sustainable tourism: a review of six cultural world heritage sites. Journal of Sustainable Tourism, 17 (1), 53-70.

Lane, B., 2009. Rural tourism: an overview. In: T. Jamal and M. Robinson, eds. The SAGE handbook of tourism studies. London: Sage Publications, 354-371.

Leal, J., 2000. Etnografias Portuguesas (1870-1970): Cultura Popular e Identidade Nacional. Lisbon: Dom Quixote.

Leite, N. and Graburn, N., 2009. Anthropological interventions in tourism studies. In: T. Jamal and M. Robinson, eds. The SAGE handbook of tourism studies. London: Sage Publications, 35-64.

Lowenthal, D., 1998. The heritage crusade and the spoils of history. Cambridge: Cambridge University Press.

MacCannell, D., (1976) 1999. The tourist: a new theory of leisure class. London: University of California Press. 
MacCannell, D., 1992. Empty meeting grounds: the tourist papers. London: Routledge.

Mathieson, A. and Wall, G., 1982. Tourism - economic, physical and social impacts. New York: Longman Group Limited.

McKean, P., 1978. Towards a theoretical analysis of tourism: economic dualism and cultural involution in Bali. In: V. Smith, org. Hosts and guests. The anthropology of tourism. Philadelphia: University of Pennsylvania Press, 119-138.

McKercher, B. and du Cros, H., 2002. Cultural tourism: the partnership between tourism and cultural heritage management. New York: The Haworth Hospitality Press.

Moon, O., 1989. From paddy field to sky slope. The revitalization of tradition in Japanese Village Life. Manchester: Manchester University Press.

MPAT and MCT, 1994. Programa de Recuperação de Aldeias Históricas de Portugal. Acção Piloto de Promoção do Potencial de Desenvolvimento Regional. Lisbon: Ministério do Planeamento e Administração do Território, Ministério do Comércio e Turismo.

Murphy, P., 1985. Tourism: a community approach. London: Routledge.

Nash, D., 1996. Anthropology of tourism. Oxford: Pergamon Press.

Orbasli, A, 2000. Tourists in historic towns. Urban conservation and heritage management. New York: E \& FN Spon.

Picard, M., 1995. Cultural heritage and tourist capital: cultural tourism in Bali. In: M.-F. Lanfant, J. Allcock and E. Bruner, eds. International Tourism, Identity and Change. London: Sage, 44-66.

Pina-Cabral, J., 1986. Sons of Adam, daughters of Eve. The peasant worldview of the Alto Minho. Oxford: Clarendon Press.

Poria, Y., Butler, R. and Airey, D., 2003. The core of heritage tourism. Annals of Tourism Research, 30 (1), 238-254.

Poria, Y. and Ashworth, G., 2009. Heritage tourism - current resource for conflict. Annals of Tourism Research, 36 (3), 522-525.

PPDR, 1995. Intervenção Aldeias Históricas de Portugal. Beira Interior. Planos das Aldeias. Lisbon: Programa de Promoção do Potencial de Desenvolvimento Regional.

Py-Sunier, O., 1978. Through native eyes: tourists and tourism in a Catalan maritime community. In: V. Smith, org. Hosts and guests. The anthropology of tourism, Philadelphia: University of Pennsylvania Press, 149-156.

Ribeiro, M. and Marques, C., 2002. Rural tourism and the development of less favoured areas: between rhetoric and practice. International Journal of Tourism Research, 4 (3), 211-220.

Richards, G., 1996. Production and consumption of European cultural tourism. Annals of Tourism Research, 23 (2), 261-283.

Robinson, M., Evans, N., Sharpley, R. and Swarbrooke, J., eds., 2000. Tourism and heritage relationships: global, national and local perspectives. Sunderland: Business Education Publishers Ltd.

Rowan, Y. and Baram, U., 2004a. Archaeology after nationalism: globalization and the consumption of the past. In: Y. Rowan and U. Baram, eds. Marketing heritage: archaeology and the consumption of the past. Walnut Creek, CA: Altamira Press, 3-26.

Rowan, Y. and Baram, U., eds., 2004b. Marketing heritage: archaeology and the consumption of the past. Walnut Creek, CA: Altamira Press.

Samuel, R., 1994. Theatres of memory: past and present in contemporary culture. London: Verso. 
Shackley, M., ed., 1998a. Visitor management: case studies from world heritage sites. Oxford: Butterworth-Heinemann.

Shackley, M., 1998b. Conclusions. In: M. Shackley, ed. Visitor management: case studies from world heritage sites. Oxford: Butterworth-Heinemann, 194-205.

Schellhorn, M., 2010. Development for whom? Social justice and the business of ecotourism. Journal of Sustainable Tourism, 18 (1), 115-135.

Sharma, B. and Dyer, P., 2009. An investigation of differences in residents' perceptions on the Sunshine Coast: tourism impacts and demographic variables. Tourism Geographies, 11 (2), 187-213.

Sharpley, R, 1999. Tourism, tourists and society. Huntingdon: Elm Publications.

Shipley, R. and Snyder, M., 2012. The role of heritage conservation districts in achieving community economic development goals. International Journal of Heritage Studies, 19 (3), 304-321.

Silva, L., 2009. Casas no Campo. Etnografia do Turismo Rural em Portugal. Lisbon: Imprensa de Ciências Sociais.

Silva, L., 2011. Beneath the surface of the heritage enterprise. Governmentality and cultural representation of rural architecture in Portugal. Ethnologia Europaea. Journal of European Ethnology, 41 (2), 39-53.

Silva, L., 2012. Built heritage-making and socioeconomic renewal in declining rural areas: evidence from Portugal. Etnográfica, 16 (3), 487-510.

Silva, L. and Santos, P.M., 2012. Ethnographies of heritage and power. International Journal of Heritage Studies, 18 (5), 437-443.

Silva, L., 2013. How ecotourism works at the community-level: the case of whalewatching in the Azores. Current Issues in Tourism, DOI: 10.1080/13683500.2013.786027. Accessed April 2013.

Silva, L. and Figueiredo, E., eds., 2013. Shaping rural areas in Europe. Perceptions and outcomes on the present and the future. Dordrecht: Springer.

Silverman, H., 2002. Touring ancient times: the present and presented past in contemporary Peru. American Anthropologist, 104 (3), 881-902.

Smith, L., 2006. Uses of heritage. New York: Routledge.

Timothy, D., 2011. Cultural heritage and tourism: an introduction. Bristol: Channel View Publications.

Tunbridge, J. and Ashworth, G., 1996. Dissonant heritage: the management of the past as a resource in conflict. Chichester: Wiley.

Urry, J., 1999. Gazing on history. In: D. Boswell and J. Evans, eds. Representing the nation: a reader. Histories, heritage and museums. London: Routledge, 208-232.

Waterton, E. and Smith, L., 2010. The recognition and misrecognition of community heritage. International Journal of Heritage Studies, 16 (1-2), 4-15.

Winter, T., 2008. Post-conflict heritage and tourism in Cambodia: the burden of Angkor. International Journal of Heritage Studies, 14 (6), 524-539.

World Bank, 2001. Cultural heritage and development: a framework for action in the Middle East and North Africa. Washington, DC: World Bank. 